DOI: http://doi.org/10.21009/JKKP.082.04

\title{
PERAN ORANG TUA DALAM MENSTIMULASI PERKEMBANGAN BAHASA ANAK USIA PRASEKOLAH
}

\author{
Maya Oktaviani ${ }^{*}$, Annisa Widya Novitasari ${ }^{2}$, Glosalalia $^{3}$, Madinatuzzahra $^{4}$, Nur Aulia $^{5}$ \\ ${ }^{1}$ Program Studi Pendidikan Kesejahteraan Keluarga, Universitas Negeri Jakarta, Jakarta, \\ 13220, Indonesia \\ 2, 3, 4, 5 Program Studi Pendidikan Bahasa Jerman, Universitas Negeri Jakarta, Jakarta, 13220, \\ Indonesia
}

${ }^{*}$ E-mail: maya.oktaviani@unj.ac.id

\begin{abstract}
Abstrak
Pertumbuhan dan perkembangan anak akan bergantung pada bagaimana stimulasi yang diberikan oleh lingkungannya. Anak usia prasekolah berada pada tahap pra operasional di mana dalam periode emas ini, anak mengalami kemajuan yang pesat dalam perkembangannya, termasuk dalam perkembangan bahasa. Perkembangan bahasa pada anak usia prasekolah memiliki tujuan agar anak mampu berkomunikasi secara lisan dengan sekitarnya. Tujuan dari penelitian ini adalah untuk menggambarkan peran orang tua dalam menstimulasi perkembangan bahasa pada anak usia prasekolah. Penelitian ini menggunakan metode kualitatif deskriptif. Penelitian dilakukan di PAUD Bintang Bangsaku, Kecamatan Cimanggis, Kota Depok pada bulan Mei hingga Juni 2021. Populasi dalam penelitian ini adalah anak usia 3-6 tahun (prasekolah). Sampel dipillih menggunakan teknik saturation sampling sebanyak 20 orang. Data dikumpulkan menggunakan angket dengan sumber data sekunder yaitu orang tua dari sampel. Data yang telah dikumpulkan selanjutnya dianalisis secara deskriptif untuk menggambarkan peran orang tua dalam menstimulasi perkembangan bahasa anak. Hasil penelitian menunjukkan bahwa orang tua memiliki banyak peran penting dalam perkembangan bahasa anak usia prasekolah. Orang tua dapat menjadi contoh dan pengawas dalam perkembangan anak. Kebersamaan antara anak dan orang tua dinilai penting karena pada usia tersebut anak masih dengan mudah menyerap sekitar. Beberapa faktor yang dapat mempengaruhi perkembangan bahasa pada anak yaitu komunikasi antara orang tua dan anak, pola asuh yang dilakukan oleh orang tua, dan pemberian fasilitas kepada anak.
\end{abstract}

Kata Kunci: peran orang tua, anak usia dini, bahasa, komunikasi

\section{The Role of Parents in Stimulating the Language Development of Preschool-Age Children}

\begin{abstract}
The growth and development of children will depend on how the stimulation provided by the environment. Preschool-age children are in the preoperational stage, wherein during this golden period, children experience rapid progress in their development, including language development. Language development in preschool-age children has a goal so that children can communicate verbally with their surroundings. This research aimed to describe the role of parents in stimulating language development in preschool-age children. This research uses the descriptive qualitative method. The study was conducted at PAUD Bintang Bangsaku, Cimanggis District, Depok City from May to June 2021. The population in this study were children aged 3-6 years (preschool). The sample was selected using the saturation sampling technique of as many as 20 people. Data were collected using a questionnaire with a secondary data source, namely the parents of the sample. The data collected was then analyzed descriptively to describe the role of parents in stimulating language development in preschool-age children. The results showed that parents have many essential roles in the language development of preschool-age children. Parents can be examples and supervisors in the development of children. Togetherness between children and parents is considered necessary because children still easily
\end{abstract}


absorb their surroundings at that age. Several factors can affect language development in children, namely communication between parents and children, parenting, and providing facilities to children.

Keywords: role of parents, preschool age children, language, communication

\section{PENDAHULUAN}

Keluarga merupakan kesatuan yang terkecil di dalam masyarakat tetapi menempati kedudukan yang sangat penting oleh sebab itu keluarga mempunyai peranan yang besar dalam mempengaruhi kehidupan seorang anak, terutama pada tahap awal maupun tahaptahap kritisnya (Masni, 2016). Anak merupakan bagian dari keluarga. Pertumbuhan dan perkembangan anak akan bergantung pada bagaimana stimulasi yang diberikan oleh lingkungannya. Orang tua berperan penting dalam membantu anak untuk mencapai tahapantahapan perkembangan anak. Proses pertumbuhan dan perkembangan seorang anak sangat pesat dan dapat berpengaruh bagi kehidupan selanjutnya (Sumaryanti, 2017). Anak yang mendapatkan nutrisi dan stimulasi yang baik, akan mencapai pertumbuhan dan perkembangan yang optimal. Salah satu perkembangan yang akan terjadi pada anak adalah perkembangan kognitif.

Anak usia prasekolah merupakan anak-anak yang berusia tiga sampai enam tahun. Pada usia ini, anak-anak berada pada periode pra operasional (Adnan et al., 2016). Perkembangan anak terdiri dari membangun pengalaman tentang dunia melalui adaptasi dan bekerja menuju tahap (konkret) ketika ia bisa menggunakan pemikiran logis. Pada periode ini, kemampuan untuk mengenal dan mengingat kembali mengalami kemajuan yang pesat termasuk perkembangan bahasanya. Bahasa adalah bentuk komunikasi (baik lisan, tulisan, atau tanda) yang didasarkan pada sebuah sistem simbol (Santrock, 2014). Bahasa terdiri dari kata-kata yang digunakan oleh suatu komunitas dan aturan-aturan untuk memvariasikan dan menggabungkannya. Bahasa adalah suatu alat verbal yang berupa lambang bunyi yang digunakan untuk berkomunikasi, berinteraksi, mengidentifikasi diri serta mengekspresikan ide, pikiran, emosi dan keyakinan (Anggraini, 2020). Perkembangan bahasa adalah kemampuan untuk memberikan respon terhadap suara, bisa mengikuti perintah ataupun bicara secara spontan (Poernomo \& Paskarinda, 2015). Dalam berbahasa, seorang anak pasti mengalami perkembangan dari waktu ke waktu yang juga dipengaruhi oleh beberapa hal seperti lingkungan sekitar dan teknologi. Anak-anak tidak belajar bahasa dengan menyerapnya secara alami. Pada usia empat tahun, anak memiliki kira-kira 1.500 hingga 2.000 kosakata. Pada usia lima tahun, anak mulai mampu untuk menjawab telepon, menghubungkan cerita, dan bertukar informasi. Pada usia prasekolah, sebagian besar anak secara bertahap menjadi lebih sensitif terhadap suara (kata-kata) yang diucapkan dan menjadi semakin mampu mengungkapkan bahasa yang dikuasai (Santrock, 2014).

Kemampuan berbahasa merupakan indikator seluruh perkembangan anak, karena kemampuan berbahasa sensitif terhadap keterlambatan atau kerusakan pada sistem lainnya yang melibatkan kemampuan kognitif, motorik, psikologis, emosi, dan lingkungan sekitar anak (Mulqiah et al., 2017). Perkembangan bahasa dimulai sejak bayi dan mengandalkan perannya pada pengalaman, penguasaan, dan pertumbuhan bahasa. Hal ini ditempuh dengan cara yang sistematis dan berkembang bersama-sama dengan pertambahan usianya. Hal inilah yang digunakan sebagai dasar mengapa anak pada umur tertentu sudah dapat berbicara, sedangkan anak yang lain dengan umur yang sama belum tentu sudah dapat berbicara pula. Akan tetapi, dalam perkembangannya, pada umumnya anak memiliki komponen pemerolehan bahasa yang hampir sama, baik perkembangan fonologinya, sintaksisnya, semantiknya, maupun pragmatiknya. Hal ini tentunya dilihat dari segi perkembangan bahasa anak yang normal.

Data di lapangan menunjukkan bahwa perkembangan bahasa anak prasekolah di Taman Kanak-kanak Kelurahan Indralaya paling banyak berada dalam kategori kurang baik (Julianti et al., 2018). Perkembangan bahasa pada anak usia prasekolah memiliki tujuan agar anak mampu berkomunikasi secara lisan dengan sekitarnya. Konteks perkembangan bahasa meliputi mendengarkan, berbicara, membaca, dan menulis dini. Dalam perkembangan 
bahasanya, anak sangat membutuhkan peran orang tua karena orang tua merupakan contoh pertama bagi sang anak. Lingkungan keluarga berpengaruh penting terhadap perkembangan anak. Semakin besar pengaruh yang diberikan lingkungannya, semakin besar pula kontribusinya bagi peningkatan keterampilan si anak dalam berbahasa (Mainizar, 2013).

Pola asuh merupakan pola interaksi antara orang tua dan anak. Sikap atau perilaku orang tua saat berinteraksi dengan anak akan memberikan dampak terhadap perkembangan anak (Tomtom, 2017). Jika pola asuh yang diberlakukan oleh orang tua adalah pola asuh yang baik, maka dampak terhadap anak akan baik. Begitupun sebaliknya, jika pola asuh yang diberlakukan oleh orang tua adalah pola asuh yang buruk, maka dampak terhadap anak akan buruk pula. Pola asuh pada anak sangat bergantung pada nilai-nilai yang dimiliki keluarga (Mulqiah et al., 2017). Mengasuh dan membesarkan anak berarti memelihara kehidupan, kesehatan, mendidik dengan penuh ketulusan dan cinta kasih (Masni, 2016).

Banyak hal yang dapat mempengaruhi perkembangan bahasa pada anak. Gaya berbicara, banyak sedikitnya interaksi yang terjadi di dalam keluarga, seringnya anak bersosialisasi, hingga pemberian fasilitas penunjang kepada anak dapat memberikan dampak bagi perkembangan bahasanya. Hal tersebut dapat berdampak positif maupun negatif. Maka dari itu, peran orang tua dinilai sangat penting karena orang tua merupakan sumber utama yang dapat mempengaruhi perkembangan pada anak, salah satunya perkembangan pada bahasa.

Penelitian terdahulu yang dilakukan oleh Mulqiah et al. (2017) menyimpulkan bahwa pola asuh orang tua memiliki hubungan yang signifikan dengan perkembangan bahasa anak prasekolah (usia 3-6 tahun) di PAUD Mustika Cempaka, Kalimantan Selatan. Hasil penelitian menunjukkan bahwa mayoritas orang tua menggunakan pola asuh demokratis yaitu sebanyak 90,9\% (40 ibu). Perkembangan bahasa anak prasekolah usia 3-6 tahun didapatkan 22,7\% (10 anak) dengan perkembangan bahasa meragukan dan 77,3\% (34 anak) dengan perkembangan bahasa yang sesuai dengan tahapan usianya.

Penelitian lainnya yang dilakukan oleh Mainizar (2013) menyimpulkan bahwa keluarga khususnya orang tua sangat berperan dalam membina dan mengembangkan kemampuan Bahasa pada anak, agar anak berkomunikasi secara aktif dan efektif dalam kehidupannya kelak ketika dia dewasa. Peranan yang dapat dilakukan oleh orang tua dalam pembinaan Bahasa adalah merintis dan meletakkan dasar berbahasa pada anak, latihan motorik, membiasakan, memelihara, mengawasi bahasa anak, dan mencegahnya berbahasa tidak sopan, dan mengembangkan kemampuan berbahasa.

Sumaryanti (2017) melalui penelitiannya menyimpulkan bahwa kemampuan berbahasa pada anak dapat berkembang seiring dengan bertambahnya pengalaman dan kebutuhan anak tersebut. Pengalaman akan didapat anak dari lingkungannya. Lingkungan merupakan salah satu faktor yang mempunyai pengaruh cukup besar bagi perkembangan bahasa anak. Karena dengan lingkungan maka anak dapat menjalani kesehariannya dengan baik tanpa adanya kesulitan dalam berinteraksi.

Berdasarkan beberapa penelitian tersebut, belum ada yang membahas mengenai bagaimana perkembangan bahasa pada anak usia prasekolah dan peran orang tua dalam menstimulasi perkembangan bahasa tersebut. Penelitian ini bertujuan Tujuan dari penelitian ini adalah untuk menggambarkan peran orang tua dalam menstimulasi perkembangan bahasa pada anak usia prasekolah.

\section{METODE}

Penelitian ini menggunakan metode kualitatif deskriptif. Penelitian dilakukan di PAUD Bintang Bangsaku, Kecamatan Cimanggis, Kota Depok pada bulan Mei hingga Juni 2021. Populasi dalam penelitian ini adalah anak usia 3-6 tahun (prasekolah). Sampel dipillih menggunakan teknik saturation sampling sebanyak 20 orang. Data dikumpulkan menggunakan angket (kuesioner) dengan sumber data sekunder yaitu orang tua dari sampel. Kuesioner yang digunakan terdiri dari 12 butir pernyataan yang dikembangkan sendiri oleh peneliti, dengan pilihan jawaban menggunakan skala frekuensi verbal (tidak pernah, jarang, 
kadang-kadang, sering, selalu). Data yang telah dikumpulkan selanjutnya dianalisis secara deskriptif untuk menggambarkan peran orang tua dalam menstimulasi perkembangan bahasa anak.

\section{HASIL DAN PEMBAHASAN}

Hasil penelitian yang melibatkan 20 anak usia prasekolah menunjukkan responden didominasi oleh anak usia lima tahun (55\%) dan enam tahun (35\%), sisanya anak usia tiga tahun $(5 \%)$ dan empat tahun $(5 \%)$. Berdasarkan data tersebut, semua sampel penelitian merupakan anak usia prasekolah. Anak-anak pada usia ini dilatih untuk belajar sekolah dengan mengikuti program PAUD.

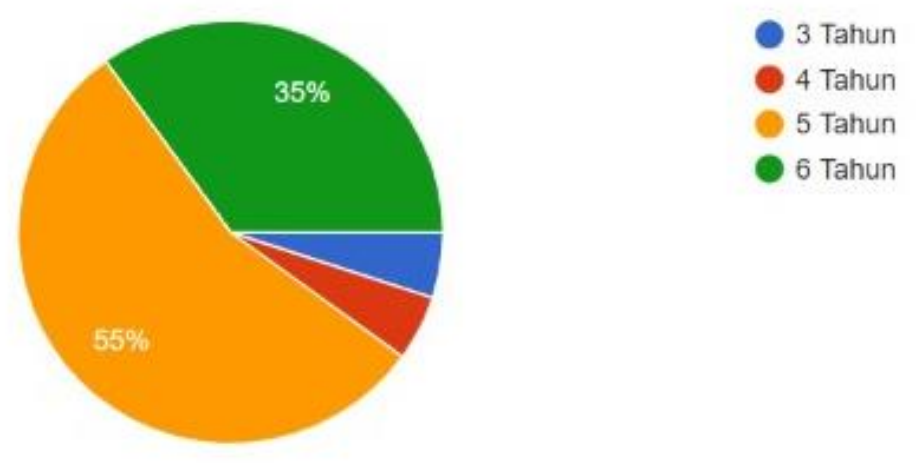

Gambar 1. Diagram Karakteristik Anak Berdasarkan Usia

Dalam kesehariannya, anak usia prasekolah menghabiskan lebih banyak waktunya bersama keluarga. Orang tua memiliki peran dalam mengawasi setiap perkembangan pada anaknya. Maka dari itu, waktu bersama antara anak dan orang tua menjadi salah satu faktor penting. Dari dua puluh anak tersebut, sebanyak 15 anak (75\%) memiliki waktu bersama orang tua lebih dari 12 jam, sebanyak empat anak (20\%) memiliki waktu bersama orang tua sebanyak 6-12 jam, dan satu anak memiliki waktu bersama orang tua kurang dari 5 jam. Kurangnya waktu yang dihabiskan bersama antara anak dan orang tua bisa disebabkan oleh status orang tua yang bekerja.

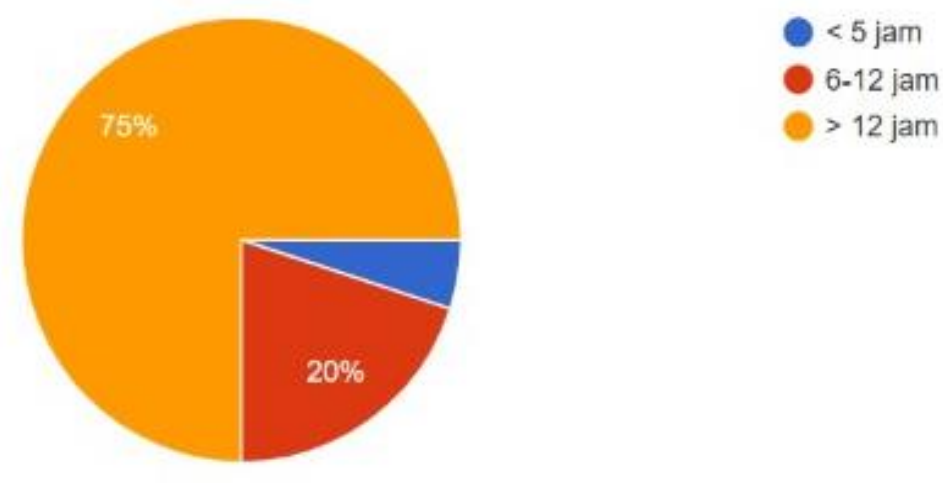

Gambar 2. Diagram Karakteristik Banyaknya Waktu yang Dihabiskan Bersama

Terdapat 12 butir pernyataan yang ada pada kuesioner. Orang tua diminta untuk mengisi sesuai keadaan anak-anaknya. Hasil penelitian menunjukkan bahwa sebanyak $75 \%$ orang tua menganggap selalu memiliki banyak waktu yang dihabiskan bersama anak, sementara $25 \%$ lainnya sering memiliki banyak waktu yang dihabiskan bersama anak. Hasil ini dapat 
menunjukkan bahwa meskipun waktu orang tua terbatas, namun orang tua memanfaatkan waktu tersebut untuk berada di sekitar anak.

Hasil penelitian menunjukan beberapa anak memiliki saudara yang dapat mempengaruhi perkembangan bahasa pada anak. Pengaruh tersebut dapat berupa gaya bicara atau kosakata yang keluar. Seorang anak dapat meniru kata-kata yang diucapkan orang lain, baik itu kata-kata yang positif maupun negatif. Dampak positifnya yaitu seorang anak bisa dengan mudah belajar dengan orang terdekat dan dapat menambah kosakata seiring berjalannya waktu. Penambahan kosakata sangat membantu anak dalam berbicara, agar anak tidak sering kehilangan kata-kata (Siti et al., 2018). Tetapi ada pula dampak negatif yang ditimbulkan yaitu jika gaya bicara atau perkataannya kurang baik, anak dapat pula meniru dan akan terekam.

Komunikasi antara orang tua dan anak dapat terjalin dengan baik jika orang tua sering mengajak anaknya berinteraksi, misalnya untuk sekadar mengobrol dan bertanya tentang kesehariannya. Komunikasi yang baik bertujuan agar tidak ada kesalahpahaman dalam menanggapi sesuatu. Hal ini juga dapat memacu perkembangan bahasa yang dimiliki anak. Semakin sering orang tua mengajak anaknya berkomunikasi atau berbicara, maka semakin banyak pula kosakata yang dimiliki oleh anak tersebut. Cara orang tua berbicara kepada anak juga berkaitan dengan peningkatan kosakata yang dikuasi anak (Santrock, 2014).

Sebanyak $60 \%$ orang tua selalu mengajak anak berkomunikasi, baik melalui tanya jawab, bercerita, atau lainnya. Kegiatan-kegiatan ini dilakukan untuk merangsang kemampuan bahasanya, baik untuk reseptif maupun ekspresif. Keterampilan bahasa reseptif meliputi kemampuan untuk mendengarkan dan membaca, sedangkan keterampilan bahasa ekspresif meliputi kemampuan untuk berbicara dan menulis (Yulsyofriend et al., 2019). Sejalan dengan hasil penelitian Simamora et al. (2019) yang menyimpulkan adanya pengaruh metode kuis/tanya jawab terhadap perkembangan bahasa anak usia 5-6 tahun di RA Al-Fajar Medan Denai. Anak-anak yang intens diajak berkomunikasi akan lebih sering menyerap kata-kata yang diucapkan orang lain. Dengan demikian, anak juga akan lebih mudah meniru ucapan orang lain. Sejalan dengan hasil penelitian Anggraini et al. (2019) yang menyatakan bahwa tahapan perkembangan bahasa anak usia dini diawali dengan proses mendengar atau menyimak.

Komunikasi yang baik antara orang tua dan anak juga menunjukkan terjalinnya hubungan yang sehat antara kedua pihak. Hal ini sejalan dengan hasil penelitian Poernomo \& Paskarinda (2015) bahwa hubungan yang sehat antara orang tua dan anak (penuh perhatian dan kasih sayang dari orang tuanya) memfasilitasi perkembangan bahasa anak, sedangkan hubungan yang tidak sehat mengakibatkan anak akan kesulitan atau kelambatan dalam perkembangan bahasanya.

Tabel 1. Distribusi Jawaban Responden

\begin{tabular}{clcccccc}
\hline \multirow{2}{*}{ No Butir Pernyataan } & & \multicolumn{5}{c}{ Persentase (\%) } \\
\cline { 3 - 7 } & $\begin{array}{c}\text { Tidak } \\
\text { Pernah }\end{array}$ & Jarang & $\begin{array}{c}\text { Kadang- } \\
\text { kadang }\end{array}$ & Sering & Selalu \\
\hline 1 & $\begin{array}{l}\text { Anak memiliki banyak } \\
\text { bersama orang tua }\end{array}$ & waktu & 0 & 0 & 0 & 25 & 75 \\
\hline 2 & $\begin{array}{l}\text { Orang tua mengajak anak } \\
\text { berkomunikasi }\end{array}$ & 0 & 0 & 15 & 25 & 60 \\
\hline 3 & $\begin{array}{l}\text { Anak meniru ucapan anggota } \\
\text { keluarga lain }\end{array}$ & 0 & 0 & 35 & 35 & 30 \\
\hline 4 & $\begin{array}{l}\text { Kata-kata yang keluar dari anggota } \\
\text { keluarga lain berpengaruh } \\
\text { terhadap gaya bicara anak }\end{array}$ & 0 & 0 & 35 & 30 & 35 \\
\hline 5 & $\begin{array}{l}\text { Orang tua memfasilitasi anak untuk } \\
\text { kemampuan berbahasa anak }\end{array}$ & 0 & 0 & 15 & 35 & 50 \\
\hline
\end{tabular}




\begin{tabular}{clccccc}
\hline \multirow{2}{*}{ Noutir Pernyataan } & \multicolumn{5}{c}{ Persentase (\%) } \\
\cline { 2 - 7 } & $\begin{array}{c}\text { Tidak } \\
\text { Pernah }\end{array}$ & Jarang & $\begin{array}{c}\text { Kadang- } \\
\text { kadang }\end{array}$ & Sering & Selalu \\
\hline 6 & $\begin{array}{l}\text { Orang tua memberi gadget untuk } \\
\text { anak bermain }\end{array}$ & 5 & 10 & 60 & 25 & 0 \\
\hline 7 & $\begin{array}{l}\text { Anak bermain dengan teman } \\
\text { sebaya }\end{array}$ & 0 & 10 & 25 & 20 & 45 \\
\hline 8 & $\begin{array}{l}\text { Orang tua bercerita atau } \\
\text { mendongeng pada anak }\end{array}$ & 0 & 15 & 55 & 20 & 10 \\
\hline 9 & $\begin{array}{l}\text { Anak bercerita kepada orang tua } \\
\text { Anak dapat dengan mudah } \\
\text { menjelaskan atau menceritakan } \\
\text { sesuatu kepada orang tua }\end{array}$ & 0 & 5 & 5 & 30 & 60 \\
\hline 11 & $\begin{array}{l}\text { Orang tua memperhatikan } \\
\text { kemampuan berbahasa anak }\end{array}$ & 0 & 0 & 5 & 35 & 45 \\
\hline 12 & $\begin{array}{l}\text { Orang tua menerapkan pola asuh } \\
\text { demokratis }\end{array}$ & 0 & 0 & 20 & 50 & 30 \\
\hline
\end{tabular}

Anak usia tiga sampai enam tahun dapat pula disebut sebagai anak usia emas (golden age), yaitu periode awal yang paling penting dan mendasar sepanjang rentang pertumbuhan dan perkembangan manusia. Pada usia ini, anak memiliki potensi yang dapat berkembang pesat jika ditangani dengan baik. Anak pada usia ini memiliki kemampuan untuk meniru sekitarnya dengan sangat baik. Maka dari itu, keluarga sebaiknya berhati-hati dalam berucap jika sedang berada di sekitar anak. Pada peniruan anak terhadap ucapan anggota keluarga lain, 30\% anak selalu meniru ucapan anggota keluarga lain, 35\% sering meniru ucapan anggota keluarga lain, dan 35\% kadang-kadang meniru ucapan anggota keluarga lain.

Selain peniruan terhadap kata-kata, gaya berbicara seseorang juga dapat mempengaruhi perkembangan bahasa anak. Bahasa yang digunakan keluarga sangat menentukan kemampuan berbahasa pada anak. Oleh karena itu, orang tua harus berkomunikasi dengan anaknya menggunakan bahasa yang baik dan lancar. Pada umumnya, orang tua di rumah sering menggunakan bahasa daerah asal dibandingkan dengan bahasa Indonesia, sehingga anak juga mampu meniru bahasa daerah tersebut. Penggunaan bahasa daerah kerapkali diiringi dengan penggunaan logat daerah. Misalnya, saat orang lain berbicara dengan nada atau logat tertentu, anak akan menirunya dan menganggap bahwa hal tersebut lumrah. Anak usia prasekolah pada zaman ini tidak hanya mengikuti gaya bicara seseorang, tapi juga mengikut gaya berbicara tokoh-tokoh kartun yang ia tonton dari televisi. Contohnya, seorang anak mengikuti gaya bicara atau logat melayu karena dia menonton "Upin \& Ipin". Dari 20 responden, 35\% orang tua menyatakan kata-kata yang keluar dari anggota keluarga lain selalu berpengaruh terhadap gaya bicara anak, 30\% orang tua menyatakan kata-kata yang keluar dari anggota keluarga lain sering berpengaruh terhadap sang anak, dan 35\% orang menyatakan kata-kata yang keluar dari anggota keluarga lain kadang-kadang berpengaruh terhadap gaya bicara anak.

Kemampuan berbahasa pada anak tidak selalu dilakukan secara otodidak, melainkan juga membutuhkan fasilitas penunjang seperti buku, belajar bersama dengan orang tua, menonton televisi atau video, sampai bersekolah. Sehingga orang tua perlu menyediakan fasilitas yang mendukung anak dalam belajar. Dalam memberi fasilitas kepada anak, orang tua harus tetap mendampingi anaknya. Hal tersebut dikarenakan terdapat juga pengaruh yang kurang baik dari fasilitas yang diberikan orang tua. Contohnya, dari menonton televisi atau video ada banyak kata-kata atau bahasa yang tidak baik. Begitu pula dengan cara pengucapan yang sering ditonton di video. Dari 20 responden, sebagian besar orang tua memfasilitasi anak untuk mengembangkan kemampuan berbahasa anak. Orang tua bertanggung jawa pada pemenuhan kebutuhan dasar anak. 
Tidak hanya itu, fasilitas seperti gadget terkadang diberikan orang tua kepada anak untuk belajar. Namun, tidak jarang pula orang tua yang memberikan gadget kepada anaknya untuk bermain atau agar anak tidak mengganggu aktivitas orang tua Ketika di rumah. Jika anak tersebut menggunakannya untuk bermain, anak hanya akan bermain sepanjang hari dan tidak jarang mengabaikan sekitarnya. Hal ini dapat berdampak buruk pada perkembangan bahasanya, karena anak kurang bersosialisasi. Selain itu, menonton video satu arah yang berlebihan akan membuat anak tidak mampu mengungkapkan ekspresinya sehingga anak tidak terlatih untuk berbicara. Di sisi yang lain, penggunaan gadget juga memberikan dampak positif yaitu anak dapat belajar mengenal teknologi. Ada banyak aplikasi atau platform yang dapat digunakan untuk melatih kemampuan anak dalam membaca, menulis, dan mendengarkan. Selain itu, penggunaan gadget juga dapat melatih bahasa kedua pada anak karena mayoritas permainan yang berada dalam ponsel memiliki bahasa asing. Dengan pengawasan dan kontrol yang baik, penggunaan gadget akan lebih banyak memberikan manfaat daripada dampak buruk. Berdasarkan hasil penelitian, sebanyak $60 \%$ orang tua kadang-kadang memberikan gadget untuk anak bermain. Namun ada juga orang tua yang tidak pernah memberikan gadget untuk anak bermain.

Bersosialisasi dengan teman sebaya merupakan salah satu hal penting untuk perkembangan anak. Anak dapat mengenal banyak orang dan memiliki teman main serta teman berkomunikasi selain keluarga di rumah. Orang tua hendaknya mengizinkan anaknya untuk bermain bersama teman sebaya karena hal tersebut dapat membuat anak lebih aktif dan agar tidak selalu bermain dengan gadget. Akan tetapi, terkadang teman sebaya juga dapat membawa pengaruh yang kurang baik karena lingkungan yang mungkin berbeda. Oleh karena itu, orang tua harus tetap mengawasi anak ketika bermain. Berdasarkan hasil penelitian, $45 \%$ orang tua menyatakan bahwa anaknya selalu bermain dengan teman sebayanya, $20 \%$ orang tua menyatakan bahwa anaknya sering bermain, $25 \%$ orang tua menyatakan kadang-kadang, dan $10 \%$ orang tua menyatakan bahwa anaknya jarang bermain dengan teman sebayanya. Selain berpengaruh pada kemampuan berbahasa, kegiatan bermain dengan teman sebaya juga akan berdampak pada perkembangan sosioemosional anak. Hal ini sesuai dengan hasil penelitian Dewi et al. (2020) bahwa perkembangan bahasa anak pada umumnya diperngaruhi oleh lingkungan anak, baik lingkungan rumah, sekolah, dan teman sebaya. Anak yang mampu berinteraksi dengan cepat akan memperoleh perkembangan bahasa, emosi, dan sosial yang cepat pula, karena anak akan banyak menghabiskan waktu dengan berinteraksi dengan orang lain.

Selain dengan berkomunikasi, memberi fasilitas, dan mengajak anak bersosialisasi, orang tua juga dapat membacakan buku cerita atau mendengarkan anak bercerita. Stimulasi bercerita penting dilakukan untuk meningkatkan perkembangan bahasa anak (Julianti et al., 2018). Orang tua tidak bisa hanya mengandalkan guru atau pendidik di sekolah yang bercerita. Membaca cerita atau dongeng dapat dilakukan saat waktu luang atau sebelum tidur. Tujuan kegiatan ini yaitu selain menambah kosakata yang dimiliki, juga meningkatkan kemampuan mendengar dan dapat mengembangkan imajinasi anak. Misalnya cerita atau dongeng tentang hewan, legenda, cerita rakyat, dan lain-lain. Anak dapat memvisualisasikan cerita tersebut dalam kehidupan sehari-hari. Jika suatu hari anak melihat wujud dari sesuatu yang ada di dalam cerita yang pernah didengarkan, anak akan mengingat kembali bagaimana alur cerita tersebut. Anak juga bisa menceritakan kembali mengenai dongeng yang pernah didengarnya. Hal ini akan memudahkan anak dalam berbicara dan membuatnya tidak pasif. Begitu juga dengan mendengarkan sang anak bercerita. Hal ini sangat penting di usia pra sekolah, karena anak sangat membutuhkan seseorang untuk menampung cerita dan pemikiran-pemikirannya. Hal ini pula dapat membantu anak dalam menyerap bahasa dan kosakata yang dikeluarkan oleh orang tua yang menanggapi mereka bercerita. Sayangnya, berdasarkan hasil penelitian, hanya $10 \%$ orang tua yang selalu bercerita atau mendongeng pada anak, $20 \%$ orang tua sering melakukannya, $55 \%$ orang tua kadang-kadang melakukannya, dan $15 \%$ orang tua jarang bercerita atau mendongeng pada anaknya.

Selain orang tua yang berperan untuk menyampaikan cerita atau bacaan kepada anaknya, orang tua juga hendaknya mengajak anak untuk menceritakan kesehariannya, 
seperti hal-hal yang anak lakukan, bercerita tentang teman-temannya, dan bercerita tentang hal baru yang anak alami. Dengan begitu, orang tua dapat mengetahui sampai mana perkembangan bahasa yang dimiliki anak dan dapat melatih anak untuk mengembangkan bahasanya dalam berbicara. Selain itu, hal tersebut merupakan salah satu cara agar komunikasi antara anak dan orang tua semakin baik. Semakin sering anak bercerita, semakin terlihat sampai mana perkembangan yang dimiliki sang anak. Dari hasil penelitian, $60 \%$ orang tua menyatakan bahwa anaknya selalu bercerita tentang kesehariannya kepada orang tua, $30 \%$ orang tua menyatakan anaknya sering bercerita kepada orang tuanya, $5 \%$ orang tua menyatakan kadang-kadang, dan $5 \%$ orang tua lagi menyatakan bahwa anaknya jarang bercerita mengenai kesehariannya kepada orang tuanya. Sikap anak yang bercerita mengenai kesehariannya kepada orang tua juga menunjukkan bahwa anak tersebut terbuka pada orang tuanya.

Walaupun anak suka bercerita kepada orang tuanya, namun tidak jarang bahwa orang tua tidak dapat atau sulit menangkap maksud dari sang anak. Seringkali anak kesulitan dalam menyampaikan beberapa hal. Hal tersebut dapat disebabkan karena kurangnya kosakata yang dimiliki anak atau anak masih kurang mampu dalam menyampaikan sesuatu. Selain itu, kurangnya kedekatan antara anak dan orang tua menyebabkan adanya batasan antara orang tua dan anak sehingga membuat anak sungkan untuk bercerita kepada orang tua. Berdasarkan hasil penelitian, $45 \%$ orang tua menyatakan bahwa anaknya selalu dapat dengan mudah menjelaskan atau menceritakan sesuatu kepada orang tuanya, 35\% orang tua menyatakan anak-anak sering menceritakan sesuatu kepada orang tuanya, dan $20 \%$ orang tua menyatakan anaknya kadang-kadang dapat dengan mudah menceritakan sesuatu dengan orang tuanya.

Mengingat pentingnya kemampuan berbahasa bagi manusia maka setiap orang tua harus menyadari tugas serta perannya dalam pembinaan bahasa pada anak walaupun secara alami bahasa seseorang akan mengalami perkembangan, sejalan dengan bertambahnya kenyataan atau pengalaman hidupnya. Bahasa seseorang akan mengalami suatu perkembangan dari waktu ke waktu sesuai bertambahnya usia, lingkungan yang sehat dan perkembangan intelektualnya. Motivasi dan intervensi orang tua dalam pengembangan bahasa anak mempermudah serta dapat mempercepat perkembangan bahasa anak melalui pembinaan bahasa yang dilakukan oleh orang tua, dengan cara yang efektif, terarah, terencana dan berkesinambungan.

Orang tua hendaknya lebih memperhatikan kemampuan bahasa sang anak. Salah satu tujuannya adalah agar bahasa yang dimiliki anak tidak menyimpang ketika anak sudah lancar berbicara. Waktu kebersamaan bersama orang tua juga tidak menjadi penghalang dalam hal ini karena orang tua dapat mengawasinya dari jarak jauh atau dengan orang kepercayaan. Perlu diperhatikan juga, orang yang dipercaya dalam pengawasan perkembangan bahasa anak juga dapat mencontohkan bahasa yang baik. Selain itu, orang tua dapat memanfaatkan waktu luang yang dimiliki meskipun sedikit untuk memantau perkembangan kemampuan anak. Berdasarkan penelitian, $50 \%$ orang tua selalu memperhatikan kemampuan berbahasa pada anaknya, $45 \%$ orang tua sering memperhatikan kemampuan berbahasa pada anaknya, dan hanya $5 \%$ orang tua yang kadang-kadang memperhatikan kemampuan berbahasa pada anaknya.

Pola asuh adalah gambaran yang digunakan oleh orang tua sebagai cara dalam mengasuh anaknya. Pola asuh orang tua terhadap anaknya juga merupakan faktor penting dalam perkembangannya. Pola asuh orang tua adalah cara orang tua untuk memperlakukan anaknya dengan menjaga, merawat, dan mendidik anaknya. Berdasarkan hasil penelitian, $30 \%$ orang tua selalu menerapkan pola asuh demokratis pada anaknya, $50 \%$ orang tua sering melakukannya, dan $20 \%$ orang kadang-kadang menerapkan pola asuh demokratis seperti menghargai pendapat anaknya. Dari cara tersebut dapat dilihat bagaimana perilaku dan karakteristik anak. Pola asuh demokratis merupakan pola asuh yang memprioritaskan atau mengutamakan kepentingan sang anak, tetapi tidak ragu-ragu dalam mengendalikan anakanaknya. Orang tua yang menerapkan pola asuh demokratis pada anaknya bersikap realistis 
atas kemampuan anaknya. Orang tua yang menerapkan pola asuh ini juga memberikan kebebasan kepada anak untuk memilih dan melakukan suatu tindakan ataupun keputusan.

Pola asuh demokratis yang diberlakukan akan menghasilkan karakteristik anak-anak yang dapat mengontrol diri, lebih mandiri, memiliki hubungan yang baik dengan lingkaran pertemanan, mampu menghadapi stres, mempunyai minat terhadap hal-hal baru dan bersifat kooperatif atau mampu bekerja sama terhadap orang-orang di sekitarnya. Berbeda dengan dampak yang dihasilkan oleh pola asuh demokratis, pola asuh otoriter justru menghasilkan dampak yang cenderung negatif, misalnya karakteristik anak tumbuh menjadi anak yang penakut, pendiam, tertutup, suka menentang, tidak berinisiatif, memiliki kepribadian yang lemah, cenderung cemas, menarik diri dari kehidupan sosial, bahkan suka melanggar norma. Dalam pola asuh permisif, dampak yang dihasilkan berupa karakteristik anak-anak yang cenderung agresif, manja, tidak patuh, kurang mandiri, mau menang sendiri, kurangnya rasa percaya diri dan kurang matang secara sosial.

Hasil penelitian ini sejalan dengan kesimpulan Tomtom (2017) bahwa perkembangan bahasa anak usia dini yang sesuai dengan standar atau di atas standar dapat tercapai dengan pola asuh demokratis. Hal ini karena pola asuh demokratis berfungsi sebagai stimulus dalam perkembangan bahasa anak usia dini. Penggalian kemampuan berbahasa dapat dilakukan dengan baik menggunakan pola asuh demokratis. Kemudian dikuatkan dengan hasil penelitian Mulqiah et al. (2017) yang menyimpulkan bahwa pola asuh orang tua memiliki hubungan yang signifikan dengan perkembangan bahasa anak prasekolah (usia 3-6 tahun) di PAUD Mustika Cempaka, Kalimantan Selatan. Hasil penelitian menunjukkan bahwa mayoritas orang tua menggunakan pola asuh demokratis.

Berdasarkan data di atas dapat terlihat bahwa orang tua memiliki peran penting dalam perkembangan bahasa pada anak usia prasekolah. Orang tua melakukan hal-hal yang dinilai dapat memacu perkembangan bahasa pada anaknya. Meskipun tidak semua orang tua dapat selalu bersama anaknya, namun waktu yang ada harus dimanfaatkan sebaik mungkin untuk mengawasi serta membimbing sehingga anak tetap dalam pengawasan orang tua dan dapat tumbuh dengan baik. Orang tua perlu memberikan stimulasi yang baik agar perkembangan bahasa anak menjadi optimal. Hal ini sejalan dengan hasil penelitian Putra et al. (2018) yang menyatakan bahwa ada pengaruh pemberian stimulasi oleh orang tua terhadap perkembangan bahasa pada anak usia toddler di PAUD Asparaga Kelurahan Merjosari Kecamatan Lowokwaru Kota Malang.

Dalam hal ini, para orang tua harus dituntut untuk cermat memilih kata yang tepat ketika berbicara dengan anak dan bijak dalam menyampaikan sesuatu hal kepada anak dengan cara yang menyenangkan. Stimulasi yang dinamis dari orang tua seperti mengajak berbicara, bernyanyi, dan mendengarkan cerita dapat merangsang penguasaan kosakata anak yang bermanfaat untuk anak berinteraksi dengan lingkungan di sekitarnya, termasuk teman sebayanya. Orang tua juga dapat menggunakan media pembelajaran yang dapat menstimulasi perkembangan bahasa anak. Seperti penelitian Siti et al. (2018) yang menggunakan flashcard sebagai media permainan edukatif untuk menstimulasi perkembangan bahasa anak usia 3-4 tahun. Selain menggunakan flashcard, stimulasi perkembangan bahasa anak juga dapat dilakukan menggunakan metode bercerita dengan memanfaatkan media big book dan boneka jari. Seperti yang dilakukan oleh Fauziah \& Rahman (2021), media big book dan boneka jari memilki peranan yang signifikan untuk meningkatkan perkembangan bahasa anak. Stimulasi ini perlu dilakukan secara berulang dan berkesinambungan.

\section{SIMPULAN DAN SARAN}

Berdasarkan hasil penelitian, orang tua memiliki banyak peran penting dalam perkembangan bahasa anak usia prasekolah. Orang tua dapat menjadi contoh dan pengawas dalam perkembangan anak. Kebersamaan antara anak dan orang tua dinilai penting karena pada usia tersebut anak masih dengan mudah menyerap sekitar, sehingga jika tidak diawasi kemungkinan anak dapat mengikuti contoh buruk yang ada di sekitar. Selain itu, pola asuh 
yang diterapkan oleh orang tua juga memiliki pengaruh dalam perkembangannya. Pola asuh yang seharusnya diterapkan yaitu pola asuh demokratis. Orang tua hendaknya lebih memperhatikan dalam prosesnya dan memberi pengetahuan kepada anak tentang apakah yang dilihat dan ditiru merupakan hal yang benar atau salah. Orang tua memberi fasilitas penunjang perkembangan bahasa tetapi tetap dengan pertimbangan yang matang dan diawasi serta memperbanyak komunikasi dengan anak. Selain untuk perkembangan bahasanya, komunikasi juga bertujuan agar hubungan antara anak dan orang tua semakin baik.

Penelitian ini terbatas pada bagaimana pentingnya peran orang tua dalam perkembangan bahasa anak. Peneliti lain dapat melanjutkan penelitian ini dengan mengembangkan media pembelajaran yang dapat menstimulasi perkembangan bahasa anak. Mengingat pentingnya peran orang tua selama anak berada pada periode emas, maka media pembelajaran sederhana yang dapat membantu orang tua menstimulasi perkembangan bahasa anak akan sangat diperlukan.

\section{DAFTAR PUSTAKA}

Adnan, E., Juriana, Issom, F. L., \& Rahmah, N. (2016). Perkembangan Peserta Didik. UNJ Press.

Anggraini, N. (2020). Peranan Orang Tua dalam Perkembangan Bahasa Anak Usia Dini. Metafora: Jurnal Pembelajaran Bahasa Dan Sastra, 7(1), 43-54. https://doi.org/10.30595/mtf.v7i1.9741

Anggraini, V., Yulsyofriend, \& Yeni, I. (2019). Stimulasi Perkembangan Bahasa Anak Usia Dini Melalui Lagu Kreasi Minangkabau pada Anak Usia Dini. Pedagogi: Jurnal Anak Usia Dini Dan Pendidikan Anak Usia Dini, 5(2), 73-84. https://doi.org/10.30651/pedagogi.v5i2.3377

Dewi, M. P., Neviyarni, \& Irdamurni. (2020). Perkembangan Bahasa, Emosi, dan Sosial pada Anak Usia Sekolah Dasar. Jurnal IImiah Pendidikan Daasar, 7(1), 1-11.

Fauziah, F., \& Rahman, T. (2021). Meningkatkan Perkembangan Bahasa Anak Usia Dini Melalui Metode Bercerita. J-SANAK: Jurnal Kajian Anak, 2(2), 108-114.

Julianti, E., Natosba, J., \& Dewi, N. R. (2018). Perkembangan Bahasa Anak Prasekolah di Taman Kanak-Kanak Kelurahan Indralaya Raya. Jurnal Keperawatan Pangkalpinang, 1(1), 54-59. http://jurnal.akperpangkalpinang.ac.id/index.php/ejkp/article/view/27

Mainizar. (2013). Peranan Orang Tua dalam Pembinaan dan Pengembangan Bahasa pada Anak Usia 2-6 Tahun. Marwah: Jurnal Perempuan, Agama Dan Jender, 12(1), 91-104. https://doi.org/10.24014/marwah.v12i1.516

Masni, H. (2016). Peran Pola Asuh Demokratis Orangtua terhadap Pengembangan Potensi Diri dan Kreativitas Siswa. Jurnal Ilmiah Dikdaya, 6(1), 58-74.

Mulqiah, Z., Santi, E., \& Lestari, D. R. (2017). Pola Asuh Orang Tua dengan Perkembangan Bahasa Anak Prasekolah (Usia 3-6 Tahun). Dunia Keperawatan, 5(1), 61-67. https://doi.org/10.20527/dk.v5i1.3643

Poernomo, D. I. S. H., \& Paskarinda, E. P. (2015). Faktor Kesehatan, Intelegensi, dan Jenis Kelamin Mempengaruhi Gangguan Perkembangan Bahasa Anak Prasekolah. Jurnal STIKES, 8(1), 23-33.

Putra, A. Y., Yudiemawati, A., \& Maemunah, N. (2018). Pengaruh Pemberian Stimulasi Oleh Orang Tua Terhadap Perkembangan Bahasa dada Anak Usia Toddler Di PAUD Asparaga Malang. Nursing News, 3(1), 563-571.

Santrock, J. W. (2014). Child Development (Fourteenth). New York: McGraw-Hill Education.

Simamora, L. H., Hasibuan, H. B., \& Lubis, Z. (2019). Pengaruh Penerapan Permainan Magic Box (Kotak Misteri) Terhadap Perkembangan Bahasa Anak Usia 5-6 Tahun di RA AlFajar Medan Denai. Jurnal Raudhah, 7(2), 91-105. https://doi.org/10.30829/raudhah.v7i2.506

Siti, R., Setyowati, A., \& Idhayanti, R. I. (2018). Media Gambar Flashcard dalam Menstimulasi Perkembangan Bahasa Anak Usia 3-4 Tahun. Jurnal Jendela Inovasi Daerah, I(2), 7892. http://jurnal.magelangkota.go.id/index.php/cendelainovasi/article/view/19 
Oktaviani, Novitasari, Glosalalia, et al., JKKP 8 (02) (2021) 153-163

Sumaryanti, L. (2017). Peran Lingkungan terhadap Perkembangan Bahasa Anak. MUADDIB, 07(01), 72-89.

Tomtom, M. A. (2017). Hubungan Pola Asuh Orang Tua dengan Perkembangan Bahasa Anak Usia Dini. Jurnal CARE (Children Advisory and Education), 4(2), 41-52.

Yulsyofriend, Anggraini, V., \& Yeni, I. (2019). Dampak Gudget Terhadap Perkembangan Bahasa Anak Usia Dini. Yaa Bunayya: Jurnal Pendidikan Anak Usia Dini, 3(1), 67-80. 